\title{
KADAR IgE PENDERITA ALERGI PADA MAHASISWA TEKNOLOGI LABORATORIUM MEDIK UNIVERSITAS MUHAMMADIYAH PURWOKERTO
}

\author{
Determination Of Ige Levels In Allergies Among Medical Laboratory Technology Students In \\ Universitas Muhammadiyah Purwokerto
}

\section{Tantri Analisawati \\ Sudarsono' \\ Dita Pratiwi Kusuma Wardani ${ }^{2 *}$}

Arif Mulyanto ${ }^{3}$

IProdi Teknologi Laboratorium Medik, FIKES, Universitas Muhammadiyah Purwokerto, Jawa Tengah, Indonesia

*2Prodi Teknologi Laboratorium Medik, FIKES, Universitas Muhammadiyah Purwokerto, Jawa Tengah, Indonesia

3Prodi Teknologi Laboratorium Medik, FIKES, Universitas Muhammadiyah Purwokerto, Jawa Tengah, Indonesia

*email: dita.tiwhie@gmail.com

\begin{abstract}
Abstrak
Prevalensi alergi semakin meningkat dari tahun ke tahun akibat pola hidup masyarakat modern. Kejadian alergi dipengaruhi oleh beberapa factor, antara lain genetic, usia, jenis kelamin, jenis makanan, dan faktor lingkungan. Penentuan kadar lgE pada usia remaja dan dewasa muda sangat penting karena kejadian alergi paling tinggi dilaporkan pada remaja dan dewasa muda. Penelitian ini bertujuan untuk menentukan kadar lgE penderita alergi pada mahasiswa Prodi Teknologi Laboratorium Medik Universitas Muhammadiyah Purwokerto. Desain penelitian berupa observasional deskriptif. Data karakteristik subyek diperoleh melalui pengisian kuesioner sedangan kadar Ig E diperoleh melalui pengukuran ELISA. Sebanyak 23 mahasiswa (4,35\% pria dan 95,65 \%wanita) dilibatkan dalam penelitian. Alergi seafood (25\%) paling umum diderita oleh subyek. Hanya $9 \%$ subyek yang memiliki alergi, Kadar IgE paling tinggi sebesar 365 $\mathrm{IU} / \mathrm{mL}$.
\end{abstract}

\begin{abstract}
The prevalence of allergies is increasing from year to year due to the modern lifestyle in society. The incidence of allergies was influenced by several factors, such as genetics, age, sex, diet, food type, and also environmental factors. Determination Ig $E$ levels in adolescents and young adults is important because the incidence of allergy is highly reported in adolescents and young adults. This study was conducted to determine Ig $E$ levels in allergies among university students in Universitas Muhammadiyah Purwokerto. This observational study was conducted among diploma students of Medical Laboratory Technology, Universitas Muhammadiyah Purwokerto. The data of characteristic subjects were collected by a self-administered questionnaire whereas data of $\lg E$ levels were collected by serum samples and measured by ELISA. A total of 23 students (4,35\% male and 95,65\% female) were included. Seafood allergy (25\%) were the commonest allergy among the students. Only $9 \%$ of subjects have combination allergies. The highest of $\mathrm{lg} E$ levels were $365 \mathrm{IU} / \mathrm{mL}$.
\end{abstract}

\section{INTRODUCTION}

The prevalence of allergies is increasing from year to year due to the modern lifestyle in society. American Academy of Allergy Asthma \& Immunology (AAAAI) reported in $2012(7,5 \%)$ of adults were diagnosed with hay fever (rhinitis allergy), anaphylaxis from drugs fatalities (20\%) leads to drug allergy, up to $50 \%$ of people the worldwide have fatality reaction in insect allergy (AAAAI, 2020). World Allergy Organization also reported the prevalence of allergies in 2013 (10-40\%) 
Tantri Analisawati Sudarsono, Dita Pratiwi Kusuma Wardani, Arif Mulyanto. 202I. Determination Of lge Levels In Allergies Among Medical Laboratory Technology Students In Universitas Muhammadiyah Purwokerto

from the total population in worldwide (Pawankar et al., 2013). Prevalence of inhalant allergy highly reported in the woman $(n=954,59,5 \%)$ and also food allergy highly reported in the woman $(n=182,60,7 \%)$ (Al-Mughales, 2016).

Allergy is a common chronic disorder that occurs in children and adults. Genetics, age, sex, diet, food type, and also environmental factors are responsible to lead to increasing the incidence of allergies. Food allergies are the commonest allergy suffers in children and adults. Many types of foods may be responsible for food allergy both children and adults include peanuts, shrimps, cornstarch, and egg white. Tomatoes, dairy milk, soybeans, wheat flour, egg yolk, chicken, tuna, and oyster maybe trigger an allergy in children (Candra, Setiarini and Rengganis, 20I I). Food allergies are highly reported in children, adolescents, and adults. Insect bite and drug allergies reported in young adult and middle age. Chemoteuraphic compounds (carboplatin and doxorubicin), herbal formulations, and oversulfated chondroitin sulfate in heparin (as a medical contaminant) are also known to trigger anaphylaxis (Siregar, 2016).

Allergies were mediated by Immunoglobulin $E$ in response to any reaction, such as urticaria and anaphylaxis. Hypersensitivity response to $\lg E$ is known to occur in patients with rhinitis allergy, asthma, and eczema were characterized by local infiltration of memory $T$ cells, eosinophils, and macrophages. Infiltrations of $\mathrm{T}$ lymphocytes with cytokines that have a major role in allergic responses (IL-4, IL-5, and IL- I3) will be found in tissues with acute inflammation. Food allergies were often reported as a result of Type I Hypersensitivity, but rarely were reported being caused by Type 2 and Type 3 Hypersensitivity (Siregar, 2016). Anaphylactic reaction involving Ig $E$ dependent immunological mechanism was triggered by food, venom insect sting, or medications but anaphylactic reaction involving Ig $E$ independent were triggered by drugs then directly activated Mast cell (Simons et al., 20II).

Several laboratory tests to diagnose allergies, such as total eosinophils measurement, total lgE, specific lgE (SPT and RAST). Total lgE measurement confirms allergy but had limitations in determining the presence or absence of an allergy. Normal Ig E levels depend on age. IgE levels in nonatopic adults were $90 \mathrm{IU} / \mathrm{mL}$ by ELISA. If we would like to find out that someone was sensitized, so measurement not only use total IgE levels but followed by a specific IgE test to avoid a false negative. A high level of total $\lg E$ or specific $\lg E$ means that a person has been sensitized with the allergen (Safri, 2008). It is important to determine $\lg E$ level in adolescents and young adults because foods, drugs, and insect bite allergies are most commonly found in adolescents and young adults (Gupta, 20I4). This study was conducted to determine $\lg \mathrm{E}$ levels in allergies among university students in Universitas Muhammadiyah Purwokerto.

\section{METHOD}

\section{Material}

Syringe (Terumo), Centrifuge (Eppendorf), tourniquet, vacutainer, gloves, masks, micropipets, tip, ELISA reader, vortex, twezeers, tube rack, plaster, absorbent paper, calori absorb tissues, plastic bag, microsentifuge tubes, alcohol swab, dry cotton, serum samples, aquabidestilata, and Immunoglobulin E (Ig G) Enzyme Immunoassay Test Kit Catalog nmber: 4S00062.

\section{Participants}

This observational study was conducted among diploma students of Medical Laboratory Technology, Universitas Muhammadiyah Purwokerto from January-February 2020. Subjects willing to participate in this study, active study grades 2016 and 2017, 18-25 years old, and the participant has no other immunologic disease were included. The subject who was not willing to participate and those not present in this study were excluded. 
Informed consent was obtained from each student. The data of characteristic subjects were self-administered questionnaire (sex, age, type of allergy, presence of multiple allergies) whereas data of total IgE levels measurement were collected using serum samples and measured by ELISA.

\section{Collecting Serum Samples}

Serum samples were collected from each subject after centrifugation and then stored in the refrigerator. About $5 \mathrm{~mL}$ sample of venous blood was drawn from each participant by venous puncture and placed in a vacuum tube for total $\mathrm{lg} E$ level determination

\section{Total IgE levels Assay}

The total IgE level was measures using the IgE Enzyme Immuno Assay Test kit. The total IgE level in normal or allergy-free adults is less than $150 \mathrm{lU} / \mathrm{mL}$ in the serum.

\section{Statistical Analysis}

Data on characteristic subjects and total Ig $E$ levels measurement were analyzed by descriptive analysis.

\section{RESULT AND DISCUSSION}

A total of 23 subjects (I (4.35 \%) male and 22 (95.65\%) female) were included. The mean age was $20.96 \pm 0.98$ years. The common allergies reported by subjects included seafood $(26,1 \%)$, detergent $(8.7 \%)$, foods, and cold (8.7\%), and cold (8,7\%). The details of characteristics subjects are detailed in Table I. Single allergic disorders were the highest frequency among respondents $(60.87 \%)$. Only $39.13 \%$ of subjects have a combination of allergic disorders. Details of allergic disorders are illustrated in Figure I. The mean of $\lg \mathrm{E}$ levels in single allergic disorders was 189.43 \pm 73.57 $\mathrm{IU} / \mathrm{mL}$ whereas the mean of $\mathrm{Ig} E$ levels in combination of allergic disorders was $174.1 \mathrm{I} \pm 62.12 \mathrm{IU} / \mathrm{mL}$.

Table I. Characteristics Subjects

\begin{tabular}{|c|c|c|c|}
\hline Characteristics & Item & $\mathbf{n}$ & $\begin{array}{c}\text { Percentage } \\
(\%)\end{array}$ \\
\hline \multirow[t]{2}{*}{ Gender } & Male & I & 4.35 \\
\hline & Female & 22 & 95.65 \\
\hline Age & Mean $\pm \mathrm{SD}$ & \multicolumn{2}{|c|}{$20.96 \pm 0.98$ years } \\
\hline \multirow[t]{2}{*}{ Allergic Disorders } & Single & 14 & 60.87 \\
\hline & Combination & 9 & 39.13 \\
\hline
\end{tabular}

Table 2. Ig E Levels Subjects

\begin{tabular}{lcccc}
\hline Allergic Disorder & $\mathbf{n}$ & $\begin{array}{c}\text { Mean } \pm \text { SD } \\
(I U / m L)\end{array}$ & $\begin{array}{c}\text { Median (Min-Max) } \\
(I U / m L)\end{array}$ \\
\hline Single & & $189.43 \pm 73.57$ & $162(I 22-365)$ \\
Combination & 14 & $174.11 \pm 62.12$ & $138(I 23-308)$ \\
\hline
\end{tabular}

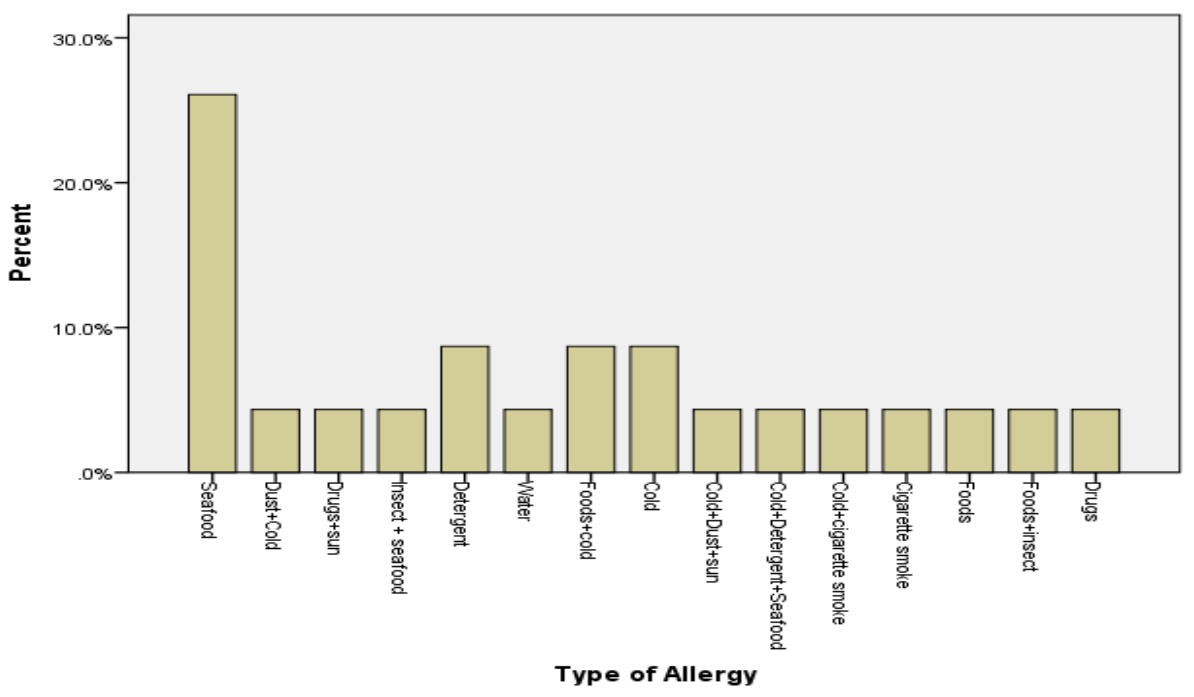


Tantri Analisawati Sudarsono, Dita Pratiwi Kusuma Wardani, Arif Mulyanto. 202I. Determination Of lge Levels In Allergies Among Medical Laboratory Technology Students In Universitas Muhammadiyah Purwokerto

Figure I. Distribution of allergic disorder in subjects

Allergy was common in females (95.65\%) than males (4.35\%) in this study. A high prevalence of allergies in females, it is similar to other studies was conducted by Hasan et al. represented $3535(64.3 \%)$ females and 1962(35.7\%) males with food allergy (Hassan et al., 2020). John et al. also reported on their studies 170(66.7\%) females and 85(33.3\%) males (John et al., 2014). Slightly difference in Azid et al. was noted 39(54.9\%) males and 32(45.1\%) females (Azid et al., 2019). Only $4.35 \%$ were enrolled as a participant in this study. The number of male participants was less than female. Similar to Couto's study reported that male participants (32.2\%) less than female participants (67.8\%) (De Paula Couto et al., 2014). Other studies proven that more than $40 \%$ of men would not seek the doctor if they were no serious health problem (Tri-city Medical Center, 2020). Based on Al- Mughales studies has no significant difference in gender comparison and age on lgE levels (AI-Mughales, 2016).

The mean age of this study was $20.96 \pm 0.98$ years similar to John et al. study. Based on Kamdar et al. studies, the high incidence of adult-onset food allergy at 23-27 years old. The history of allergy occurred starting at 18-27 years old but the highest frequency of required epinephrine at 48-57 years old. Shellfish was known to triggered adult-onset allergy and other food following ackee fruit, apple, basil, buckwheat, beef, homemade beer, celery, corn, cottonseed oil, ginger, green beans, green pepper, mango, nectarine, paprika, peach, pork, potato, spinach, tomato, and zucchini (John et al., 20I4; Kamdar et al., 2015).

A Seafood allergy is the highest frequency in this study (25\%). Allergic reactions to seafood can be mild urticaria and oral allergy syndrome to life-threatening anaphylaxis reactions. Moreover, reactions to seafood can get worse after consumption of fish containing
Anisakis larvae which is a reaction similar to seafood allergy. Other reaction such as histamine fish poisoning (HFP) and intolerance to histamine can trigger clinical symptoms (Prester, 2016).

The concentration of $\lg E$ in serum is affected by age. Low serum levels are found in bone marrow serum $(<4.8 \mathrm{ng} / \mathrm{mL}$ ) with a progressive increase until the age of 15 years, while total IgE levels will decline from the second to the eighth decade (Ansotegui et al., 2020). The results of the study of $\lg E$ levels that exceeded the normal value $>150 \mathrm{IU} / \mathrm{mL}$ were in line with the results of Azid's studies which showed total Ig E levels> 100 $\mathrm{kU} / \mathrm{l}$. Ig E plays an important role in mediating allergic sensitization to some extent. Levels $>100 \mathrm{kU} / \mathrm{I}$ is recommended for the diagnosis of allergies in adults (Azid et al., 2019). Dendritic cells, B cells, interleukin-4 (IL-4), IL-I3 have a major role in the production of antigen specific IgE. They present the processed antigens to cognate naive $T$ Cells that then acquire a $T$ Helper 2 (TH 2) molecular phenotype which is both engage cognate $B$ Cells through $B$ cell major histocompatibility complex (MHC) class II and costimulatory and also secrete IL-4 and IL- 13 then inducing $B$ cells to undergo class- switch recombination (CSR) (Galli and Tsai, 2013)

Environmental factors that play a role in the development of allergies, including food \& nutrition, air pollution, airborne allergens, urbanization, germs, infections and infestations, contact allergens and irritants, emotional factors, stress, pollution, climate changes, gene interactions, microbes,modifying allergen carrier such as pollen (Jenerowicz et al., 2012; Gilles et al., 2018)

\section{CONCLUSION}


From the research results, it can be concluded that the highest IgE levels come from sufferers of seafood allergy. Determination of IgE levels with the IgE Enzyme Immuno Assay Test kit can be used as a diagnostic tool. It is necessary to conduct a study regarding the measurement of specific IgE levels with specific diagnostic tools.

\section{UNKNOWNLEDGEMENT}

This study was supported by LPPM UMP Grant [grant number: Al I-III/4 I9-S.Pj/LPPM/XI/2019]

\section{REFERENCES}

I. AAAAI (2020) Allergy Statistics | AAAAI, American Academy of Allergy Asthma \& Immunology. Available at: $\quad$ https://www.aaaai.org/aboutaaaai/newsroom/allergy-statistics (Accessed: 14 September 2020).

2. Al-Mughales, J. A. (20I6) 'Diagnostic Utility of Total IgE in Foods, Inhalant, and Multiple Allergies in Saudi Arabia', Journal of Immunology Research, 2016. doi: $10.1155 / 2016 / 1058632$.

3. Candra, Y., Setiarini, A. and Rengganis, I. (20II) 'Gambaran Sensitivitas Terhadap Alergen Makanan', Makara Kesehatan, I5(I), pp. 44-50. Available at: http://journal.ui.ac.id/index.php/health/ article/ download/797/759.

4. Siregar, S. P. (2016) 'Peran Alergi Makanan dan Alergen Hirup pada Dermatitis Atopik', Sari Pediatri, 6(4), p. I55. doi: I0.14238/sp6.4.2005.I558.

5. Simons, F. E. R. et al. (20II) 'World allergy organization guidelines for the assessment and management of anaphylaxis', World Allergy Organization Journal, 4(2), pp. 13-37. doi: 10.1097/WOX.0b013e3182II496c.

6. Safri, M. (2008) 'Standar emas pemeriksaan alergi makanan pada anak', Jurnal Kedokteran Syiah Kuala, 8(3), pp. I5I-I56.

7. Gupta, R. S. (20I4) 'Anaphylaxis in the young adult population', American Journal of Medicine, I27(I SUPPL.), PP. SI7-S24. doi: I0.1016/j.amjmed.2013.09.010.

8. Hassan, A. et al. (2020) 'Food allergy among university students: Uncharted territory', Allergy, Asthma and Clinical Immunology, I6(I), PP. I-6. doi: I0.1|86/s |3223-020-04|5-5.

9. John, L. J. et al. (2014) 'Prevalence of Allergies among University Students: A Study from Ajman, United Arab Emirates', ISRN Allergy, 2014, pp. I-5. doi: 10.1 I55/2014/502052.

10. Azid, N. et al. (2019) 'Total IgE levels and their Relevance in the Diagnosis of Allergy Among Malaysian Population in the North- East Region of Peninsular Malaysia', 4(2), pp. I-7.

II. De Paula Couto, T. A. P. et al. (20/4) 'Total ige plasma levels vary according to gender and age in brazilian patients with allergic rhinitis', Clinics, 69(II), Pp. 740-744. doi: 10.606 I/clinics/20 |4(I I)06.

12. Tri-city Medical Center (2020) Why Don't Men Go to the Doctor as Often as Women? | Tri-City Medical Center. Available at: https://www.tricitymed.org/2017/06/dont-men-godoctor-often-women/ (Accessed: 3 October 2020).

13. Kamdar, T. A. et al. (2015) 'Prevalence and characteristics of adult-onset food allergy', J Allergy Clin Immunol Pract, 3(I), pp. II4-5. doi: 10.1016/j.jaip.2014.07.007

14. Prester, L. (2016) 'Seafood Allergy, Toxicity, and Intolerance: A Review', Journal of the American College of Nutrition, 35(3), pp. 27I-283. doi: 10.1080/073|5724.2015.10|4|20.

15. Ansotegui, I. J. et al. (2020) 'IgE allergy diagnostics and other relevant tests in allergy, a World Allergy Organization position paper', World Allergy Organization Journal, I3(2). doi: 10.1016/j.waojou.2019.100080.

16. Galli, S. J. and Tsai, M. (20/3) ' $\mathrm{gEE}$ and mast cells in allergic disease', Nat Med, I8(5), pp. 693-704. doi: 10.1038/nm.2755.lgE.

17. Jenerowicz, D. et al. (20I2) 'Environmental factors and allergic diseases', Annals of Agricultural and Environmental Medicine, 19(3), pp. 475-48I.

18. Gilles, S. et al. (20|8) 'The role of environmental factors in allergy: A critical reappraisal', Experimental Dermatology, 27(II), pp. II93-1200. doi: 10.1 I I I/exd. I3769.

19. Pawankar, R. et al. (20I3) WAO White Book on Allergy: Updates 2013, World Allergy Organization. 
Tantri Analisawati Sudarsono, Dita Pratiwi Kusuma Wardani, Arif Mulyanto. 202I. Determination Of Ige Levels In Allergies Among Medical Laboratory Technology Students In Universitas Muhammadiyah Purwokerto

Available at:

https://www.worldallergy.org/UserFiles/file/White

Book2-2013-v8.pdf (Accessed: 14 September

2020). 